\title{
Drying Characteristics of Zucchini and Empirical Modeling of Its Drying Process
}

\author{
NACIYe KUtlu ${ }^{\mathrm{a}}$ AND Asli Isca ${ }^{\mathrm{a}^{*}}$ \\ ${ }^{a}$ Ankara University, Faculty of Engineering, Department of Food Engineering, Ankara, Turkey \\ ${ }^{*}$ Corresponding author \\ isci@ankara.edu.tr \\ TEL: $+90-312-2033300$ \\ FAX: $+90-312-3178711$
}

Received: 27 January 2017; Published online: 18 October 2017

\begin{abstract}
The aim of the study was to dry zucchini (Cucurbita pepo) by two different methods (convective hot-air (CHD) and microwave-assisted drying (MWD)). The effect of air temperature (60, 70 and $\left.80^{\circ} \mathrm{C}\right)$, microwave $(\mathrm{MW})$ power $(180,360,540 \mathrm{~W})$ and sample thickness $(5$ and $10 \mathrm{~mm})$ on some drying characteristics of zucchini were investigated. Thirteen mathematical models available in the literature were fitted to the experimental moisture ratio data. The coefficients of the models were determined by non-linear regression analysis. It was determined that the model that fits the moisture ratio data the best varies at different drying conditions. Increasing drying temperature and MW power and reducing sample thickness improved the drying rate and drying time. Drying in microwave has reduced the drying time by $52-64 \%$ for zucchini. It was found that the effective moisture diffusivities increased with increasing temperature and MW power. MWD samples had better rehydration ratios compared to ones dried only in tray drier for $5 \mathrm{~mm}$ thickness.
\end{abstract}

Keywords: Convective hot-air; Drying; Microwave-assisted drying; Thin layer models; Zucchini

\section{Introduction}

Zucchini that are also known as courgettes, belong to the species Cucurbita pepo. This vegetable originated from Italy and can be cultivated easily in temperate climates. Zucchini are mostly made up of water and thus it is very low in calories. The mean water content of zucchini is $13.28 \mathrm{~kg}_{\text {water }} \mathrm{kg}_{\text {drymatter }}{ }^{-1}$. According to the USDA National Nutrient Database (USDA, 2014) one medium fresh zucchino has 33 calories, 2.37 grams of protein, 6.1 grams of carbohydrate and 2 grams of fiber. Zucchini are also a good source of folic acid, vitamin $\mathrm{A}$, vitamin $\mathrm{C}$ and minerals. They are highly perishable and deteriorate rapidly after slicing, due to firmness loss, browning and decay. Coating with edible films, canning, freezing, salting, vacuum packing, irradiation and drying are some of the preservation methods that can be applied to preserve zucchini. Among these, drying is one of the oldest and most commonly used methods of food preservation. Dried zucchini can be used in soup mixes, casseroles, seasoning mixes, or it can simply be consumed as a nutritious snack food.

The main purpose of drying is to decrease water activity of the food to extend its shelf life. In addition, drying minimizes packaging, storage and transportation costs by substantially reducing the weight of the product. Open sun-drying is the traditional dehydration method. However, issues related to hygiene, very long drying time and low final product quality has led researchers to investigate different types of dry- 
ing methods such as solar cabinet dryers, tray dryers, fluidized bed dryers, vacuum freeze dryers and etc. Among these, convection hot air drying (CHD) is one of the most popular heating methods in food systems. Many studies have been published on CHD characteristics of various vegetables and fruits such as eggplant (Akpinar \& Bicer, 2005), cherry tomato (Heredia, Barrera, \& Andres, 2007), okra (Adedeji, Gachovska, Ngadi, \& Raghavan, 2008), sour cherry (Aghbashlo, Kianmehr, \& Hassan-Beygi, 2010) and peach (Zhu \& Shen, 2014). However information on drying characteristics of zucchini is lacking in literature.

Microwaves are defined as electromagnetic waves with specific ranges of frequencies between 300 $\mathrm{MHz}$ and $300 \mathrm{GHz}$ (Schubert \& Regier, 2005). The dielectric materials such as food can be heated by microwaves due to molecular vibration as a result of dipolar rotation or ionic conduction (Lebovka, Praporscic, Ghnimi, \& Vorobiev, 2005). Water is the major chemical constituent of nearly all food products, because of its dipolar nature, is the main source of microwave interactions (Sumnu, 2001). Microwave energy is currently being used in industrial food processing for the purpose of cooking, tempering, blanching, melting, drying etc. (Basak \& Rao, 2011). Microwave heating is one of the promising technologies that have the ability to penetrate the material and heat it volumetrically. Other advantages of microwave application include reduced processing time, environmental impact and power consumption (Datta, 2001). Many studies have been performed on MW or MW-assisted drying of food. Some examples include drying of carrot (Arikan, Ayhan, Soysal, \& Esturk, 2012), spinach (Ozkan, Akbudak, \& Akbudak, 2007), tomato pomace (Al-Harahsheh, Al-Muhtaseb, \& Magee, 2009) and apple (Zarein, Samadi, \& Ghobadian, 2015). Similar to CHD, there is no information in literature regarding the MWD of zucchini.

Drying process involves simultaneous and often coupled and multiphase, heat, mass, and momentum transfer phenomena (Kudra \& Mujumdar, 2002). It is one of the most complex and least understood processes (Erbay \& Icier, 2010). Thin layer drying equations are important tools in mathematical modeling of drying. Thin layer drying generally means to dry the food material as one layer of slices (Akpinar, 2006). The temperature distribution inside the food material can be easily assumed as uniform due to its thin structure (Erbay \& Icier, 2010). Thin layer drying equations have been widely applied due to their ease of use and less data requirement. The most commonly used and newly developed thin layer drying models in food engineering have been summarized by Erbay and Icier (2010). Even though many studies have been performed on mathematical modeling of drying, knowledge on drying kinetics of zucchini is lacking in literature. Therefore, the main purpose of the present work was to determine the effect of different drying methods (CHD and MWD) and process variables (air temperature, MW power, and sample thickness) on some characteristics of zucchini. It was also aimed to fit the experimental data to semi-theoretical models which are widely used to describe thin layer drying behavior of agricultural products.

\section{Materials and Methods}

\subsection{Raw material}

Zucchini samples used in the study were purchased during winter season from a local market in Ankara, Turkey. The samples were not peeled. They were cleaned and cut at two different thicknesses (5 and $10 \mathrm{~mm})$. The samples had a mean diameter of $50 \pm 2 \mathrm{~mm}$. The moisture contents of the samples were analyzed by infrared moisture analyzer (HB43-S, Metter Toledo, USA) at $105^{\circ} \mathrm{C}$. Initial moisture content of the fresh zucchini samples were $13.28 \pm 0.01$ $\mathrm{kg}_{\text {water }} \mathrm{kg}_{\text {drymatter }}{ }^{-1}$.

\subsection{Convective hot-air drying}

CHD experiments were performed using a tray drier constructed by Inoksen AS Company in Turkey. It consists of a centrifugal fan to supply the air, an electrical heater, an air filter and a proportional temperature controller. The air velocity was measured with an anemometer (DT8894, CEM, China). The samples were dried on trays $\left(15^{*} 30 \mathrm{~cm}\right)$ that are connected to a weigh-

IJFS | October 2017 | Volume 6 | pages 232-244 
ing unit (Accuracy: $0.01 \mathrm{~g}$ ). Dryer had three tier trays and the samples were placed in a single row on the trays. The zucchini samples were dried at different temperatures $\left(60,70\right.$ and $\left.80^{\circ} \mathrm{C}\right)$. The mean percent relative humidity of air at different drying temperatures was measured as 4.87 , 3.68 and $2.08 \%$ for 60,70 and $80^{\circ} \mathrm{C}$, respectively. The air velocity was kept constant $\left(2 \mathrm{~m} \mathrm{~s}^{-1}\right)$ during the experiments. The weight of samples was recorded at 30 min intervals and drying was continued until no further changes in their mass were observed. The dried samples were cooled in desiccator and vacuum packed in heat sealed lowdensity polyethylene bags.

\subsection{Microwave drying}

Microwave experiments were performed using a programmable domestic microwave oven (GMOM 25, General Electric, USA) with maximum output of $900 \mathrm{~W}$. The dimensions of the microwave cavity were $215 \mathrm{~mm}$ by $350 \mathrm{~mm}$ by $330 \mathrm{~mm}$. The oven was fitted with a glass turntable (314 $\mathrm{mm}$ diameter) and had a digital control facility to adjust the microwave output power and the time. The zucchini samples were first dehydrated partially at $80^{\circ} \mathrm{C}$ before MWD. The partial dehydration was performed using the tray drier mentioned above until the moisture content of $2.33 \pm 0.005 \mathrm{~kg}_{\text {water }} \mathrm{kg}_{\text {drymatter }}{ }^{-1}$ was achieved. The partially dehydrated samples were, then, subjected to MWD at different powers $(180,360,540 \mathrm{~W})$ until no further changes in sample mass was observed. The weight loss of samples was determined at $30 \mathrm{~s}$ intervals by using a digital balance (ATX-224, Shimadzu, Japan).

\subsection{Rehydration ratio}

The rehydration ratio (RR) of dehydrated zucchini samples were evaluated by immersing dried samples in water at $25^{\circ} \mathrm{C}$ for $24 \mathrm{~h}$. The rehydration ratio was calculated as amount of water absorbed $(\mathrm{g})$ per g of dry material. The rehydration ratio (RR) was calculated using Equation (1). All of the experiments and analysis mentioned above were performed in duplicates.

$$
R R=\frac{\text { water absorbed }(\mathrm{g})}{\text { amount of dry matter }(\mathrm{g})}
$$

\subsection{Thin layer modeling of drying curves}

Moisture ratio (MR) of the samples was calculated using the following equation:

$$
M R=\frac{M_{t}-M_{e}}{M_{0}-M_{e}}
$$

where, $\mathrm{M}_{t}, \mathrm{M}_{0}$ and $\mathrm{M}_{e}$ are the moisture content at time $\mathrm{t}$, the initial moisture content and the equilibrium moisture content of the sample $\left(\mathrm{kg}_{\text {water }} \mathrm{kg}_{\text {drymatter }}{ }^{-1}\right)$, respectively. The drying rate was calculated using Equation (3):

$$
\frac{\Delta M}{\Delta t}=\lim _{\Delta t \rightarrow 0}\left(M_{t+\Delta t}-M_{t} / \Delta t\right)
$$

Where $\Delta \mathrm{M} / \Delta \mathrm{t}$ is the drying rate $\left(\mathrm{kg}_{\text {water }}\right.$ $\left.\mathrm{kg}_{\text {drymatter }}{ }^{-1} \mathrm{~min}^{-1}\right), \mathrm{M}$ is the moisture content of the sample at any time $\left(\mathrm{kg}_{\text {water }} \mathrm{kg}_{\text {drymatter }}\right.$ $\left.{ }^{-1}\right), \mathrm{t}$ is time $(\mathrm{min})$ and $\Delta \mathrm{t}$ is time increment (min).

Thirteen different thin layer models which are widely used to describe drying behavior of agricultural products were selected (Table 1) to fit the experimental data. These mathematical models are generally derived by simplifying general series solution of Fick's second law (Wang, Sun, Chen, Liao, \& Hu, 2007). The coefficients of the models are determined by non-linear regression analysis using SigmaPlot 11.0 (Systat Software Inc., USA) program. The accuracy of fit was determined using the three statistical parameters; correlation coefficient $\left(\mathrm{R}^{2}\right)$, the reduced Chi-square $\left(\chi^{2}\right)$ and the root mean square error (RMSE). These parameters can be calculated as follows:

$$
\begin{gathered}
\chi^{2}=\frac{\sum_{i=1}^{N}\left(M R_{e x p, i}-M R_{p r e, i}\right)^{2}}{N-n} \\
R M S E=\left[\frac{1}{N} \sum_{i=1}^{N}\left(M R_{\text {exp }, i}-M R_{p r e, i}\right)^{2}\right]^{\frac{1}{2}}
\end{gathered}
$$

Where $\mathrm{MR}_{\text {exp }, i}$ and $\mathrm{MR}_{\text {pre }, i}$ are the experimental and predicted moisture ratios at observation $i$, respectively. $N$ is the number of experimental data points and $\mathrm{n}$ is the number of constants in the model. The higher values of $\mathrm{R}^{2}$ and lower values of $\chi^{2}$ and RMSE are chosen as the criteria for goodness of fit. 
Table 1: Thin layer drying models

\begin{tabular}{lll}
\hline Model & Model Name & References \\
\hline $\mathrm{MR}=\exp (-\mathrm{kt})$ & Newton & Ayensu (1997) \\
$\mathrm{MR}=\exp \left(-\mathrm{kt}^{n}\right)$ & Page & Sarsavadia, Sawhney, Pangavhane, and Singh (1999) \\
$\mathrm{MR}=\exp \left[(-\mathrm{kt})^{n}\right]$ & Modified Page I & Yaldiz and Ertekin (2001) \\
$\mathrm{MR}=\exp \left[-(\mathrm{kt})^{n}\right]$ & Modified Page II & Yaldiz and Ertekin (2001) \\
$\mathrm{MR}=\mathrm{a} \exp (-\mathrm{kt})$ & Henderson \& Pabis & Bengtsson, Rahman, Stanley, and Perera (1998) \\
$\mathrm{MR}=\mathrm{a} \exp (-\mathrm{kt})+\mathrm{c}$ & Logarithmic & Sacilik (2007) \\
$\mathrm{MR}=\mathrm{a} \exp \left(-\mathrm{k}_{o} \mathrm{t}\right)+\mathrm{b} \exp \left(-\mathrm{k}_{1} \mathrm{t}\right)$ & Two-term & Madamba, Driscoll, and Buckle (1996) \\
$\mathrm{MR}=\mathrm{a} \exp (-\mathrm{kt})+(1-\mathrm{a}) \exp (-\mathrm{kat})$ & Two-term exponential & Sharafeldeen, Blaisdell, and Hamdy (1980) \\
$\mathrm{MR}=1+\mathrm{at}+\mathrm{bt}{ }^{2}$ & Wang \& Sing & Wang and Singh (1978) \\
$\mathrm{MR}=\mathrm{a} \exp (-\mathrm{kt})+(1-\mathrm{a}) \exp (-\mathrm{kbt})$ & Diffusion approach & Kassem (1998) \\
$\mathrm{MR}=\mathrm{a} \exp (-\mathrm{kt})+(1-\mathrm{a}) \exp (-\mathrm{gt})$ & Verma et al. & Verma, Bucklin, Endan, and Wratten (1985) \\
$\mathrm{MR}=\mathrm{a} \exp (-\mathrm{kt})+\mathrm{b} \exp (-\mathrm{gt})+\mathrm{c} \exp (-\mathrm{ht})$ & Modified Henderson \& Pabis & Karathanos (1999) \\
$\mathrm{MR}=\mathrm{a} \exp \left(-\mathrm{kt}^{n}\right)+\mathrm{bt}$ & Midilli & Midilli, Kucuk, and Yapar (2002) \\
\hline
\end{tabular}

\subsection{Calculation of effective diffusivity $\left(\mathbf{D}_{e f f}\right)$ and activation energy $\left(\mathrm{E}_{a}\right)$}

Diffusion is a characteristic behavior in a drying process. Drying characteristics of biological materials in falling rate period can be determined by Fick's second law (Wang et al., 2007). The equation was solved by (Crank, 1975) with some assumptions. These assumptions are:

- Moisture was transferred only by diffusion;

- No couplings between heat and mass transfers;

- Shrinkage was negligible;

- Temperature and diffusion coefficients did not change throughout drying;

- Drying time was long.

The final equation obtained was:

$$
M R=\frac{8}{\pi^{2}} \sum_{n=0}^{\infty} \frac{1}{(2 n+1)^{2}} e^{\left(-\frac{[2 n+1]^{2} \pi^{2} D_{\text {eff }} t}{4 L^{2}}\right)}
$$

Where $\mathrm{D}_{\text {eff }}$ is the effective diffusivity $\left(\mathrm{m}^{2} \mathrm{~s}^{-1}\right)$, $\mathrm{L}$ is half thickness of samples $(\mathrm{m})$ and $\mathrm{t}$ is the drying time ( $\mathrm{s})$. For long drying time, this equation can be simplified as:

$$
M R=\frac{8}{\pi^{2}} e^{\left(-\frac{\pi^{2} D_{e f f} t}{4 L^{2}}\right)}
$$

Taking the logarithmic of both sides of the equation would give:

$$
\ln M R=\ln \frac{8}{\pi^{2}}-\frac{\pi^{2} D_{e f f} t}{4 L^{2}}
$$

ln MR versus drying time gives a straight line with a slope (K) (Wang et al. (2007)):

$$
K=\left(\pi^{2} D_{e f f}\right) /\left(4 L^{2}\right)
$$

The effect of the temperature on the effective diffusivity was expressed using the Arrhenius-type relationship for both CHD (10) and MWD (11) (Dadali, Apar, and Ozbek (2007)):

$$
D_{e f f}=D_{0} e^{\left(-\left(E_{A} /(R T)\right)\right)}
$$

$$
D_{e f f}=D_{0} e^{\left(-\left(E_{A} m /(P)\right)\right)}
$$

Where $\mathrm{E}_{A}$ is activation energy $\left(\mathrm{kj} \mathrm{mol}^{-1}\right.$ or $\mathrm{W}$ $\left.\mathrm{g}^{-1}\right), \mathrm{D}_{0}$ is pre-exponential factor of Arrhenius equation $\left(\mathrm{m}^{2} \mathrm{~s}^{-1}\right), \mathrm{R}$ is universal gas constant $\left(\mathrm{kj} \mathrm{mol}^{-1} \mathrm{~K}^{-1}\right)$, $\mathrm{T}$ is drying temperature $(\mathrm{K})$, $\mathrm{m}$ is sample weight $(\mathrm{g}), \mathrm{P}$ is $\mathrm{MW}$ power $(\mathrm{W})$.

\subsection{Statistical analysis}

Statistical analysis was performed using the software MINITAB 15.1.1.0 (Minitab, State Collage, 
PA, USA). The comparisons were made using Tukey's test with a significance level of 0.05 .

\section{Results and Discussion}

\subsection{Convective hot-air drying}

Zucchini slices were dried at different temperatures $\left(60,70\right.$ and $\left.80^{\circ} \mathrm{C}\right)$ and thicknesses ( 5 and $10 \mathrm{~mm}$ ). The moisture content of samples was reduced from $13.28 \pm 0.01 \mathrm{~kg}_{\text {water }} \mathrm{kg}_{\text {drymatter }}{ }^{-1}$ to $0.08 \pm 0.007 \mathrm{~kg}_{\text {water }} \mathrm{kg}_{\text {drymatter }}{ }^{-1}$. The effect of temperature and slice thickness on moisture ratio (MR) and drying rate were depicted in Figs. 1 and 2, respectively. It was observed that moisture ratio decreased continuously with drying time. It was also found that air temperature and sample thickness had a significant impact on drying rates (Fig. 2). As it was expected, drying took place in the falling rate period during which the drying rate decreased continuously with a decrease in moisture ratio. Initially the drying rate was higher, because at the early stages of drying moisture emigrates from regions close to surface. As drying progresses, moisture diffuses from parenchymal cells within the structure and must be transported to the surface. Hence, reduced rates are observed at lower moisture contents.

Similar to drying rates, drying times were also greatly affected by the process parameters (Table 2). At constant sample thickness, increasing temperature from 60 to $80^{\circ} \mathrm{C}$, has decreased the drying time by 20 and $26 \%$ for 5 and $10 \mathrm{~mm}$ samples, respectively. Decreasing sample thickness from $10 \mathrm{~mm}$ to $5 \mathrm{~mm}$ at constant temperature caused an average of $54 \%$ reduction in drying time. Halving the slice thickness reduced the resistance to both heat and mass transfer which proportionally affected the drying time. Zhu and Shen (2014) also observed that halving the slice thickness (from 0.004 to $0.002 \mathrm{~m}$ ) had decreased the drying time $50 \%$ for peach samples. Similar results regarding the effect of air temperature and slice thickness were also reported in literature for eggplant (Ertekin \& Yaldiz, 2004) and apple (Meisami-asl, Rafiee, Keyhani, \& Tabatabaeefar, 2009).

The moisture ratio data were fitted to thir- teen different thin layer drying models (Table $1)$. RMSE (root mean square error), $\chi^{2}$ (chisquare) and $R^{2}$ (coefficient of determination) values were used to compare the relative goodness of fit of experimental data. The results showed that Midilli and Wang \& Sing models gave the superior fit to the experimental data compared to other models (Table 3). Similar to our findings, Doymaz (2011) also reported that drying data of eggplant were best represented by Logarithmic, Wang \& Sing and Midilli models. In addition, Midilli model was found to be the best fitting model for apple and tomato as well (Meisami-asl et al., 2009; Taheri-Garavand, Rafiee, \& Keyhani, 2011).

The $\mathrm{D}_{\text {eff }}$ values for different slice thicknesses and temperatures were given in Table 4. The effective diffusivities of zucchini samples varied from $0.58 \times 10^{-9}$ to $1.93 \times 10^{-9} \mathrm{~m}^{2} \mathrm{~s}^{-1}$. The effective moisture diffusivities increased with an increase in temperature and slice thickness. When samples were dried at higher temperature, the increase in heating energy would increase the activity of water molecules leading to higher moisture diffusivity (Xiao et al., 2010). The effects of air temperature and slice thickness on $\mathrm{D}_{\text {eff }}$ values were also observed by other researchers. Doymaz (2004) stated that $\mathrm{D}_{\text {eff }}$ values of carrot were in the range of $0.776-9.335 \times 10^{-9} \mathrm{~m}^{2}$ $\mathrm{s}^{-1}$. They have also observed that increasing slice thickness from 1 to $2 \mathrm{~cm}$ at constant air flow rate and temperature caused an increase in effective moisture diffusivity. In addition, Zhu and Shen (2014) have observed similar results for peach samples $\left(\mathrm{D}_{\text {eff }}\right.$ values $4.15-11.07 \times 10^{-10} \mathrm{~m}^{2}$ $\mathrm{s}^{-1}$. ).

Arrhenius-type relationship between $\mathrm{D}_{\text {eff }}$ and air temperature was shown in Fig. 3. The activation energies were calculated as 32.58 and $36.55 \mathrm{kj} \mathrm{mol}^{-1}$ for 5 and $10 \mathrm{~mm}$ samples, respectively. These values were similar to those estimated by different authors, for example: 38.78 $\mathrm{kj} \mathrm{mol}^{-1}$ for Cape gooseberry (Vega-Galvez, Puente-Diaz, Lemus-Mondaca, Miranda, \& Torres, 2014), $42.53 \mathrm{kj} \mathrm{mol}^{-1}$ for peach (Zhu \& Shen, 2014) and $30.58 \mathrm{kj} \mathrm{mol}^{-1}$ for garlic slices (Demiray \& Tulek, 2014).

Rehydration of dried food is an important property to characterize the quality of products. Water must be absorbed rapidly in a greater vol- 
ume as possible (Cunningham, Mcminn, Magee, \& Richardson, 2008). The maximum rehydration ratios were 5.56 and 5.18 ( $\mathrm{g}_{\text {waterabsorbed }}$ $\mathrm{g}_{\text {drymatter }}{ }^{-1}$ ) for 5 and 10 samples (Fig. 4). Similar rehydration values were also reported in literature for potato (Cunningham et al., 2008) and Amasya apple (Doymaz, 2010). It was also found that the process parameters did not exhibit any statistically significant impact on rehydration ratios. Since the degree of rehydration is dependent on the degree of cellular and structural disruption suffered during drying, it may be stated that CHD caused similar modification of structure on zucchini at different air temperatures and slice thicknesses.

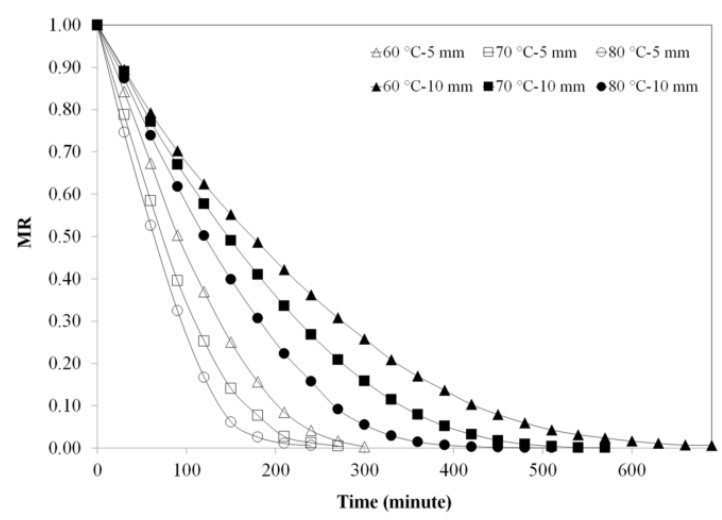

Figure 1: Effect of temperature and slice thickness on moisture ratio (MR) for CHD

\subsection{Microwave drying}

Zucchini samples were also dried at different MW powers (180, 360 and $540 \mathrm{~W}$ ) and slice thicknesses ( 5 and $10 \mathrm{~mm}$ ). The partial dehydration was performed using the tray drier until the moisture content of samples was reduced from $13.28 \pm 0.01 \mathrm{~kg}_{\text {water }} \mathrm{kg}_{\text {drymatter }}{ }^{-1}$ to $2.33 \pm 0.005 \mathrm{~kg}_{\text {water }} \mathrm{kg}_{\text {drymatter }}{ }^{-1}$. During MWD, the moisture content of samples was reduced from $2.33 \pm 0.005 \mathrm{~kg}_{\text {water }} \mathrm{kg}_{\text {drymatter }}{ }^{-1}$ to $0.07 \pm 0.005 \mathrm{~kg}_{\text {water }} \mathrm{kg}_{\text {drymatter }}{ }^{-1}$. The changes in moisture ratio and drying rate were presented in Figs. 5 and 6. Similar to CHD, the moisture ratio decreased continuously with the dry-

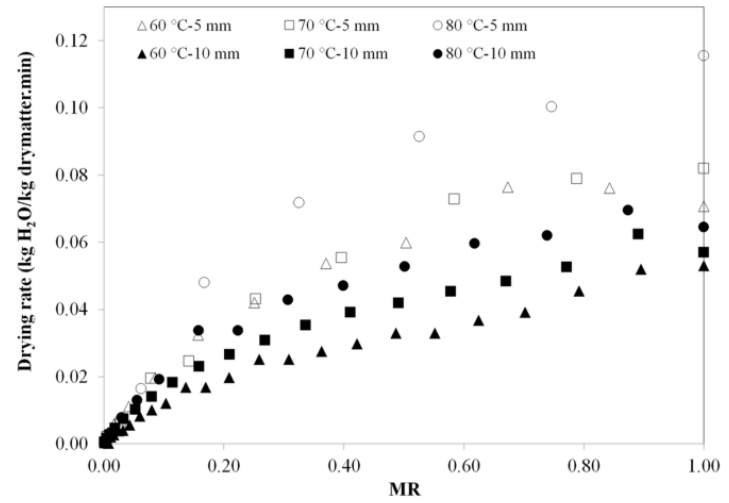

Figure 2: Effect of temperature and slice thickness on drying rate for $\mathrm{CHD}$

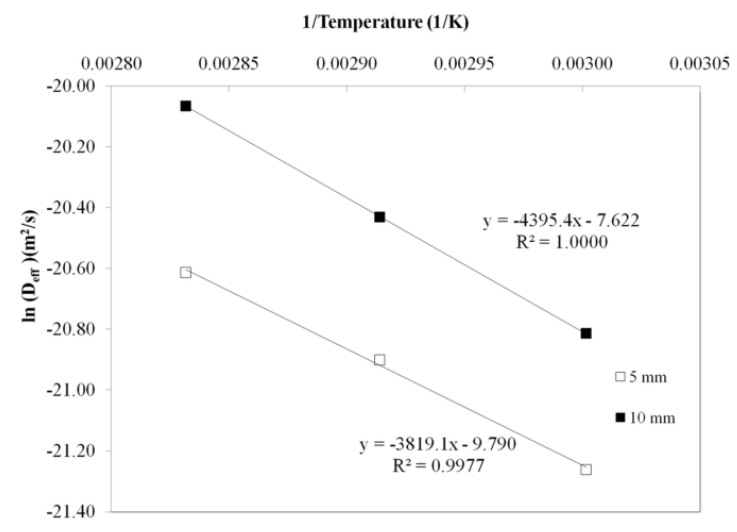

Figure 3: Arrhenius-type relationship between Deff and temperature at different sample thicknesses

ing time. However, unlike hot air drying both constant and falling rate periods were observed for MWD samples. These results were in agreement with the study of parsley and okra that were dried by MW (Soysal, 2004; Dadali et al., 2007). MW power and samples thickness had an influence on drying rates and drying times. The drying times for zucchini samples were shown in Table 5. At constant sample thickness, increasing MW power from 180 to $540 \mathrm{~W}$ has decreased the drying time by $82 \%$ and $73 \%$ for 5 and 10 mm samples, respectively. In addition, halving the slice thickness has decreased the drying time 
Table 2: Drying times at different process conditions for CHD

\begin{tabular}{ccc}
\hline Drying Temperature $\left({ }^{\circ} \mathrm{C}\right)$ & Slice Thickness $(\mathrm{mm})$ & Drying time $(\mathrm{min})$ \\
\hline 60 & 5 & 300 \\
70 & 5 & 270 \\
80 & 5 & 240 \\
60 & 10 & 690 \\
70 & 10 & 570 \\
80 & 10 & 510 \\
\hline
\end{tabular}

Table 3: Statistical parameters and coefficients of models at different process conditions for CHD

\begin{tabular}{ccccccccc}
\hline Model & Process Conditions & RMSE & $\chi^{2}$ & $\mathrm{R}^{2}$ & $\mathrm{a}$ & $\mathrm{k}$ & $\mathrm{n}$ & $\mathrm{b}$ \\
\hline Midilli & $60{ }^{\circ} \mathrm{C}-5 \mathrm{~mm}$ & 0.0003 & 0.00001 & 0.9995 & $9.94 \times 10^{-1}$ & $1.47 \times 10^{-3}$ & 1.357 & $-13.71 \times 10^{-5}$ \\
Midilli & $70{ }^{\circ} \mathrm{C}-5 \mathrm{~mm}$ & 0.0015 & 0.00001 & 0.9994 & $9.94 \times 10^{-1}$ & $2.23 \times 10^{-3}$ & 1.338 & $-8.62 \times 10^{-5}$ \\
Wang \& Sing & $80^{\circ} \mathrm{C}-5 \mathrm{~mm}$ & 0.0064 & 0.00005 & 0.9988 & $-9.50 \times 10^{-3}$ & - & - & $2.26 \times 10^{-5}$ \\
Midilli & $60{ }^{\circ} \mathrm{C}-10 \mathrm{~mm}$ & 0.0001 & 0.00001 & 0.9987 & $9.82 \times 10^{-1}$ & $1.44 \times 10^{-3}$ & 1.193 & $-5.85 \times 10^{-5}$ \\
Wang \& Sing & $70{ }^{\circ} \mathrm{C}-10 \mathrm{~mm}$ & 0.0021 & 0.00001 & 0.9997 & $-4.00 \times 10^{-3}$ & - & - & $0.40 \times 10^{-5}$ \\
Midilli & $80{ }^{\circ} \mathrm{C}-10 \mathrm{~mm}$ & 0.0047 & 0.00003 & 0.9983 & $9.81 \times 10^{-1}$ & $0.82 \times 10^{-3}$ & 1.402 & $-3.88 \times 10^{-5}$ \\
\hline
\end{tabular}

Table 4: $\mathrm{D}_{\text {eff }}$ values at different process conditions for CHD

\begin{tabular}{cc}
\hline $\begin{array}{c}\text { Process Conditions } \\
\text { (Slice thickness-Air temperature) }\end{array}$ & $\mathrm{D}_{\text {eff }}\left(\mathrm{m}^{2} \mathrm{~s}^{-1}\right)$ \\
\hline $5 \mathrm{~mm}-60{ }^{\circ} \mathrm{C}$ & $0.58 \times 10^{-9}$ \\
$5 \mathrm{~mm}-70{ }^{\circ} \mathrm{C}$ & $0.84 \times 10^{-9}$ \\
$5 \mathrm{~mm}-80{ }^{\circ} \mathrm{C}$ & $1.12 \times 10^{-9}$ \\
$10 \mathrm{~mm}-60{ }^{\circ} \mathrm{C}$ & $0.91 \times 10^{-9}$ \\
$10 \mathrm{~mm}-70{ }^{\circ} \mathrm{C}$ & $1.34 \times 10^{-9}$ \\
$10 \mathrm{~mm}-80{ }^{\circ} \mathrm{C}$ & $1.93 \times 10^{-9}$ \\
\hline
\end{tabular}

Table 5: Drying times at different process conditions for MWD

\begin{tabular}{cccccc}
\hline $\begin{array}{c}\text { MW Power } \\
(\mathrm{W})\end{array}$ & $\begin{array}{c}\text { Slice Thickness } \\
(\mathrm{mm})\end{array}$ & $\begin{array}{c}\text { Partial Dehydration } \\
\text { Period }(\min )\end{array}$ & $\begin{array}{c}\text { Drying Time } \\
\text { in MW }(\mathrm{s})\end{array}$ & $\begin{array}{c}\text { Total Drying } \\
\text { Time }(\mathrm{min})^{a}\end{array}$ & $\begin{array}{c}\text { Time Saved } \\
(\%)\end{array}$ \\
\hline 180 & 5 & 100 & 510 & 108.5 & 64 \\
360 & 5 & 100 & 150 & 102.5 & 62 \\
540 & 5 & 100 & 90 & 101.5 & 58 \\
180 & 10 & 240 & 900 & 255 & 63 \\
360 & 10 & 240 & 300 & 245 & 57 \\
540 & 10 & 240 & 240 & 244 & 52 \\
\hline
\end{tabular}

${ }^{a}$ Includes the time required for partial dehydration $\left(80^{\circ} \mathrm{C}\right)$ before MWD. 
Table 6: Statistical analysis and coefficients of models at different process conditions for MWD

\begin{tabular}{cccccccccccc}
\hline Model & $\begin{array}{c}\text { Process } \\
\text { Conditions }\end{array}$ & RMSE & $\chi^{2}$ & $\mathrm{R}^{2}$ & $\mathrm{c}$ & $\mathrm{a}$ & $\mathrm{k}$ & $\mathrm{n}$ & $\mathrm{b}$ & & \\
& & & & & & & \\
\hline Logarithmic & $180 \mathrm{~W}-5 \mathrm{~mm}$ & 0.0018 & 0.00001 & 0.9984 & $-2.35 \times 10^{-1}$ & 1.228 & $3.28 \times 10^{-3}$ & - \\
Midilli & $360 \mathrm{~W}-5 \mathrm{~mm}$ & 0.0045 & 0.00006 & 0.9996 & - & 0.998 & $1.78 \times 10^{-3}$ & 1.432 & $-4.77 \times 10^{-4}$ \\
Midilli & $540 \mathrm{~W}-5 \mathrm{~mm}$ & 0.0101 & 0.00040 & 1.0000 & - & 1.000 & $3.24 \times 10^{-3}$ & 1.542 & $-2.83 \times 10^{-4}$ \\
Wang \& Sing & $180 \mathrm{~W}-10 \mathrm{~mm}$ & 0.0008 & 0.00001 & 0.9992 & - & -0.001 & - & - & $3 \times 10^{-7}$ \\
Midilli & $360 \mathrm{~W}-10 \mathrm{~mm}$ & 0.0042 & 0.00003 & 0.9985 & - & 0.988 & $1.16 \times 10^{-3}$ & 1.354 & $-2.04 \times 10^{-4}$ \\
Midilli & $540 \mathrm{~W}-10 \mathrm{~mm}$ & 0.0052 & 0.00005 & 0.9994 & - & 1.002 & $0.13 \times 10^{-3}$ & 1.787 & $-4.74 \times 10^{-4}$ \\
\hline
\end{tabular}

Table 7: $\mathrm{D}_{\text {eff }}$ values at different process conditions for MWD samples

\begin{tabular}{cc}
\hline $\begin{array}{c}\text { Process Conditions } \\
\text { (Slice thickness-Microwave power) }\end{array}$ & $\mathrm{D}_{\text {eff }}\left(\mathrm{m}^{2} \mathrm{~s}^{-1}\right)$ \\
\hline $5 \mathrm{~mm}-180 \mathrm{~W}$ & $1.65 \times 10^{-8}$ \\
$5 \mathrm{~mm}-360 \mathrm{~W}$ & $5.21 \times 10^{-8}$ \\
$5 \mathrm{~mm}-540 \mathrm{~W}$ & $16.91 \times 10^{-8}$ \\
$10 \mathrm{~mm}-180 \mathrm{~W}$ & $2.63 \times 10^{-8}$ \\
$10 \mathrm{~mm}-360 \mathrm{~W}$ & $10.20 \times 10^{-8}$ \\
$10 \mathrm{~mm}-540 \mathrm{~W}$ & $11.05 \times 10^{-8}$ \\
\hline
\end{tabular}

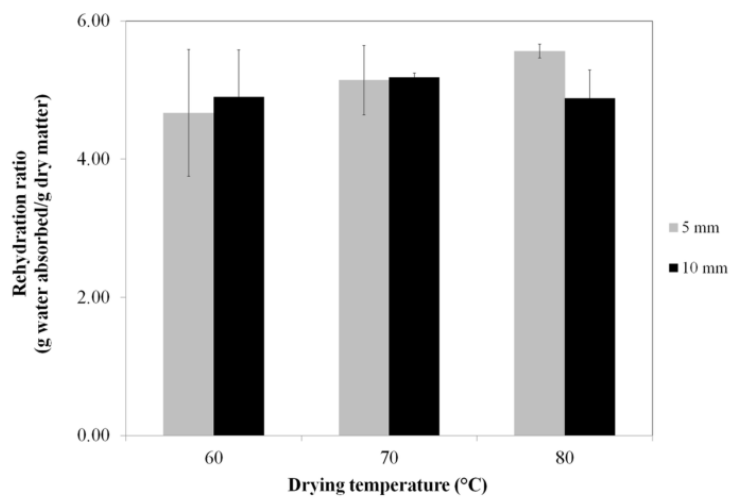

Figure 4: Rehydration ratios of zucchini at different process conditions for CHD

by $43 \%, 50 \%$ and $63 \%$ for 180,360 and $540 \mathrm{~W}$, respectively. The positive effect of MW power on drying time was also reported in literature for spinach, leek and okra (Ozkan et al., 2007; Dadali \& Ozbek, 2008; Apar, Demirhan, Ozbek, \& Dadali, 2009).

As mentioned in materials and methods section,

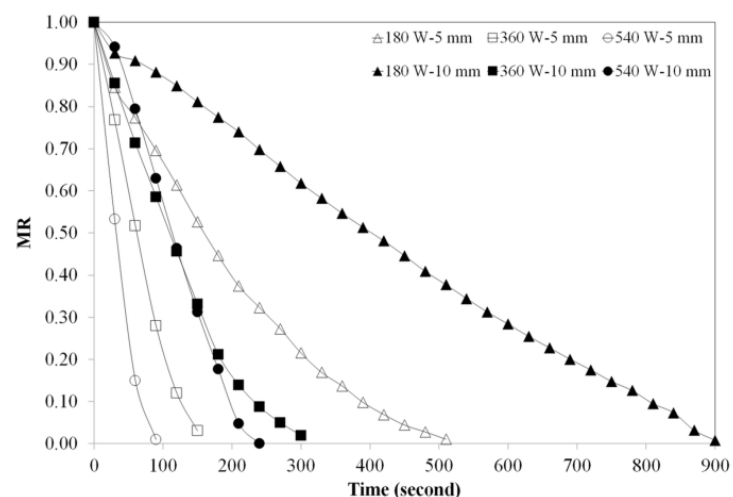

Figure 5: Effect of microwave power and slice thickness on moisture ratio (MR)

zucchini samples were first dehydrated partially at $80^{\circ} \mathrm{C}$ before MWD. Total drying times at different process conditions were also presented in Table 5 . The results suggested that total drying time was reduced about $52-64 \%$ when partially dehydrated zucchini was dried by MWD instead of CHD. This indicates that MWD can signifi- 


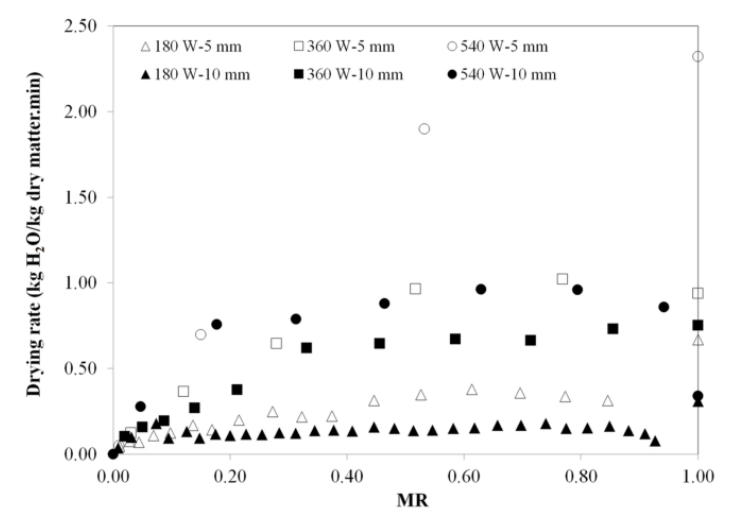

Figure 6: Effect of microwave power and slice thickness on drying rate

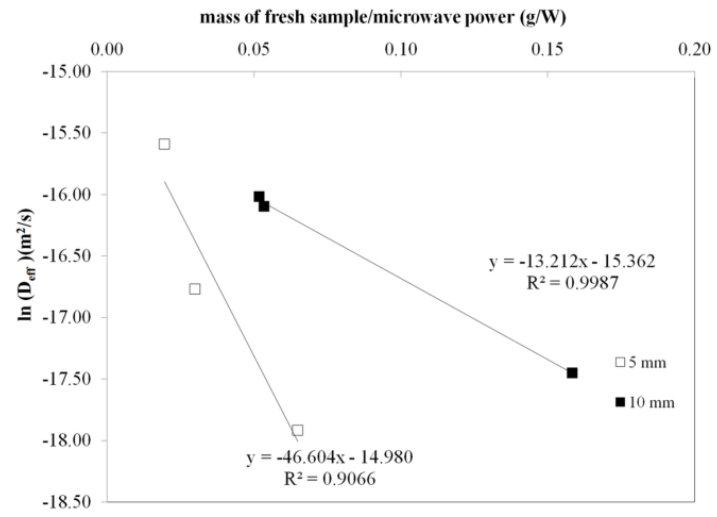

Figure 7: Arrhenius-type relationship between $\mathrm{D}_{\text {eff }}$ and microwave power at different sample thicknesses

cantly reduce drying time and might save energy. Similar results were also reported in literature. Maskan (2000) observed that MW finish drying reduced the CHD time by about $64.3 \%$ for banana slices. Izli and Isik (2015) stated that the drying time of tomato samples decreased from 780 to $80 \mathrm{~min}$ when the samples were dried by $\mathrm{MW}$ at $500 \mathrm{~W}$ instead of $75^{\circ} \mathrm{C} \mathrm{CHD}$.

Similar to $\mathrm{CHD}$, the moisture ratio obtained during MWD was also fitted to thirteen thin layer models (Table 1). Logarithmic, Midilli and Wand \& Sing were found to be the best fitting models at different process conditions (Table 6).

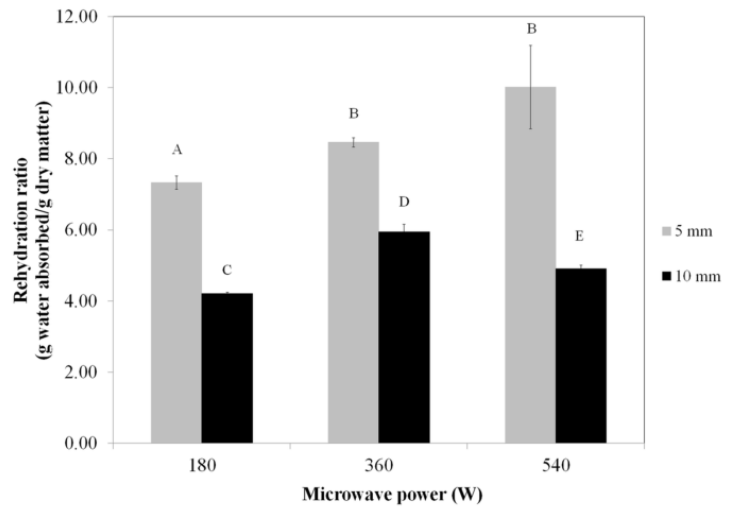

Figure 8: Rehydration ratios of zucchini at different process conditions for MWD

Parallel results were also observed in literature for different foods. Karaaslan and Tuncer (2008) stated that Midilli was the best fitting model for spinach dried at different MW powers. Logarithmic model was found to represent the drying characteristics of pomegranate arils dried by MW (Calin-Sanchez et al., 2014). Izli, Yildiz, Unal, Isik, and Uylaser (2014) reported that Midilli and Wang \& Sing models were the most successful in describing the drying behavior of golden berry. $\mathrm{D}_{\text {eff }}$ values of MWD samples (Table 7) were calculated using Equation 11. The effective diffusivity values varied from $1.65-16.91 \times 10^{-8} \mathrm{~m}^{2} \mathrm{~s}^{-1}$ for $5 \mathrm{~mm}$ slices thickness and $2.63-11.05 \times 10^{-8}$ $\mathrm{m}^{2} \mathrm{~s}^{-1}$ for $10 \mathrm{~mm}$ slice thickness. Increasing MW power, resulted in higher effective diffusivities at constant slice thickness. Our results were in agreement with the findings of Ozbek and Dadali (2007) and Minaei, Motevali, Najafi, and Mousavi Seyedi (2012). They found that increasing MW power caused an increase in effective moisture diffusivity. In our study, it was also found that effective moisture diffusivities were about 10 times higher in MWD compared to CHD. Singh, Nair, Rahimi, Gariepy, and Raghavan (2013) have also reported that effective moisture diffusivity of MWD potato was about 5 times higher than that of hot-air dried samples.

The activation energy values were calculated by plotting $\ln \mathrm{D}_{e f f}$ vs. ratio of fresh sample mass to 
MW power $\left(\mathrm{m} \mathrm{P}^{-1}\right)$ (Fig. 7) and were found as 46.6 and $13.2 \mathrm{~W} \mathrm{~g}^{-1}$ for $5 \mathrm{~mm}$ and $10 \mathrm{~mm}$ samples, respectively. Similar results were reported for MW dried pomegranate arils and apple (Minaei et al., 2012; Zarein et al., 2015). The activation energies were reported as 12.30, 24.22 and $12.15 \mathrm{~W} \mathrm{~g} \mathrm{~g}^{-1}$, respectively.

The maximum rehydration ratios (Fig. 8) for the MWD samples were 10.01 and 5.94 $\left(\mathrm{g}_{\text {waterabsorbed }} \mathrm{g}_{\text {drymatter }}{ }^{-1}\right)$ for 5 and 10 samples, respectively. The results showed that rehydration ratio of the samples that were dried at $180 \mathrm{~W}$ were lower for both 5 and $10 \mathrm{~mm}$ samples $(p<0.05)$. In other words, rehydration ratio of zucchini samples was affected negatively at low MW power. In addition, it was observed that rehydration ratio was reduced with the increase in slice thickness. This may be due to prolonged drying times observed with the thicker samples. As the drying process gets longer, the cellular and structural disruption that takes place during dehydration may also increase. The maximum rehydration ratio was observed at the process condition that resulted in minimum drying time (5mm sample thickness, $540 \mathrm{~W}$ MW power) which also indicated that drying time affected the cell structure and the rehydration ratio of zucchini significantly. Moreover, rehydration ratio of MWD zucchini was approximately 2-fold higher than that of hot-air dried ones for $5 \mathrm{~mm}$ samples. Our findings were consistent with the literature. In general, a significant increase was observed in rehydration ratio when food samples were dried by MWD rather than hot-air drying (Drouzas \& Schubert, 1996). On the other hand, $10 \mathrm{~mm}$ zucchini samples that were MWD and hot-air dried had very close rehydration ratios. This result signified that MWD may be a better method for preserving the cell structure of thinner zucchini samples.

\section{Conclusions}

The effects of drying temperature, MW power and thickness of zucchini slice on drying characteristics were investigated in CHD and MWD. The different process conditions were found to have a significant effect on drying rates of zucchini samples. Microwave application decreased the drying time significantly (about 52-64\%). The drying behavior of zucchini samples was explained by fitting the moisture ratio data to thirteen thin layer drying models. Goodness of the models was determined by statistical parameters such as $\mathrm{R}^{2}, \chi^{2}$ and RMSE. The results showed that Logarithmic, Midilli and Wang \& Sing models gave the superior fit to the experimental data. The effective diffusivity values were varied in the range of $0.58-1.93 \times 10^{-9}$ and 1.65 $16.91 \times 10^{-8} \mathrm{~m}^{2} \mathrm{~s}^{-1}$ for CHD and MWD, respectively. The activation energies of 5 and $10 \mathrm{~mm}$ samples were calculated as $32.58-36.55 \mathrm{~kJ} \mathrm{~mol}^{-1}$ for hot-air drying and 46.6-13.2 $\mathrm{W} \mathrm{g}^{-1}$ for MWD. Samples dried in MWD had better rehydration ratios compared to ones dried only in tray drier for $5 \mathrm{~mm}$ samples, indicating that MWD could be a better option for preserving the cell structure of thinner zucchini samples.

\section{Acknowledgements}

The authors thank Dr. Suna Ertunc for her contribution with SigmaPlot training.

\section{References}

Adedeji, A. A., Gachovska, T. K., Ngadi, M. O., \& Raghavan, G. S. V. (2008). Effect of pretreatments on drying characteristics of okra. Drying Technology, 26(10), 12511256. doi:10.1080/07373930802307209

Aghbashlo, M., Kianmehr, M. H., \& HassanBeygi, S. R. (2010). Drying and rehydration characteristics of sour cherry (Prunus Cerasus 1.) Journal of Food Processing and Preservation, 34(3), 351-365. doi:10.1111/ j.1745-4549.2008.00310.x

Akpinar, E. K. (2006). Determination of suitable thin layer drying curve model for some vegetables and fruits. Journal of Food Engineering, 73(1), 75-84. doi:10.1016/j. jfoodeng.2005.01.007

Akpinar, E. K. \& Bicer, Y. (2005). Modelling of the drying of eggplants in thin-layers. International Journal of Food Science and Technology, 40(3), 273-281. doi:10.1111/j. 1365-2621.2004.00886.x 
Apar, D. K., Demirhan, E., Ozbek, B., \& Dadali, G. (2009). Rehydration kinetics of microwave-dried okras as affected by drying conditions. Journal of Food Processing and Preservation, 33(5), 618-634. doi:10. 1111/j.1745-4549.2008.00277.x

Arikan, M. F., Ayhan, Z., Soysal, Y., \& Esturk, O. (2012). Drying characteristics and quality parameters of microwave-dried grated carrots. Food and Bioprocess Technology, 5(8), 3217-3229. doi:10.1007/s11947-011$0682-8$

Ayensu, A. (1997). Dehydration of food crops using a solar dryer with convective heat flow. Solar Energy, 59(4-6), 121-126. Proceedings of ISES 1995: Solar World Congress, HARARE, ZIMBABWE, SEP 09-16, 1995. doi:10.1016/S0038-092X(96)00130-2

Basak, T. \& Rao, B. S. (2011). Role of ceramic composites and microwave pulsing on efficient microwave processing of pork meat samples. Food Research International, 44(9), 2679-2697. doi:10.1016/j. foodres.2011.05.034

Bengtsson, G., Rahman, M. S., Stanley, R., \& Perera, C. O. (1998). Effect of specific pretreatment on the drying behaviour of apple rings. In Proceedings of the new zealand institute of food science and technology and the nutrition society of new zealand conference, nelson, new zealand.

Calin-Sanchez, A., Figiel, A., Szarycz, M., Lech, K., Nuncio-Jauregui, N., \& CarbonellBarrachina, A. A. (2014). Drying kinetics and energy consumption in the dehydration of pomegranate (Punica granatum l.) arils and rind. Food and Bioprocess Technology, 7(7), 2071-2083. doi:10.1007/s11947-013$1222-5$

Crank, J. (1975). The mathematics of diffusion. Oxford: Clarendon Press. Retrieved from http : / / www - eng . lbl . gov / shuman / NEXT / MATERIALS \% 26COMPONENTS / Xe_damage / Crank The-Mathematics-of-Diffusion.pdf

Cunningham, S. E., Mcminn, W. A. M., Magee, T. R. A., \& Richardson, P. S. (2008). Experimental study of rehydration kinetics of potato cylinders. Food and Bioprocess
Technology, 86(C1), 15-24. doi:10.1016/ j.fbp.2007.10.008

Dadali, G. \& Ozbek, B. (2008). Microwave heat treatment of leek: drying kinetic and effective moisture diffusivity. International Journal of Food Science and Technology, 43(8), 1443-1451. doi:10.1111/j.1365-2621. 2007.01688.x

Dadali, G., Apar, D. K., \& Ozbek, B. (2007). Microwave drying kinetics of okra. Drying Technology, 25 (4-6), 917-924. doi:10.1080/ 07373930701372254

Datta, A. K. (2001). Handbook of microwave technology for food application. CRC Press.

Demiray, E. \& Tulek, Y. (2014). Drying characteristics of garlic (Allium sativum l) slices in a convective hot air dryer. Heat and Mass Transfer, 50(6), 779-786. doi:10 . 1007/s00231-013-1286-9

Doymaz, I. (2004). Convective air drying characteristics of thin layer carrots. Journal of Food Engineering, 61(3), 359-364. doi:10. 1016/S0260-8774(03)00142-0

Doymaz, I. (2010). Effect of citric acid and blanching pre-treatments on drying and rehydration of amasya red apples. Food and Bioprocess Technology, 88(C2-3), 124-132. doi:10.1016/j.fbp.2009.09.003

Doymaz, I. (2011). Drying of eggplant slices in thin layers at different air temperatures. Journal of Food Processing and Preservation, 35(2), 280-289. doi:10.1111/j.17454549.2009.00454.x

Drouzas, A. E. \& Schubert, H. (1996). Microwave application in vacuum drying of fruits. Journal of Food Engineering, 28(2), 203209. doi:10.1016/0260-8774(95)00040-2

Erbay, Z. \& Icier, F. (2010). A review of thin layer drying of foods: theory, modeling, and experimental results. Critical Reviews in Food Science and Nutrition, 50(5), 441464. doi:10.1080/10408390802437063

Ertekin, C. \& Yaldiz, O. (2004). Drying of eggplant and selection of a suitable thin layer drying model. Journal of Food Engineering, 63(3), 349-359. doi:10.1016/j . jfoodeng . 2003.08.007

Al-Harahsheh, M., Al-Muhtaseb, A. H., \& Magee, T. R. A. (2009). Microwave drying kinetics of tomato pomace: effect of 
osmotic dehydration. Chemical Engineering and Processing, 48(1), 524-531. doi:10. 1016/j.cep.2008.06.010

Heredia, A., Barrera, C., \& Andres, A. (2007). Drying of cherry tomato by a combination of different dehydration techniques. comparison of kinetics and other related properties. Journal of Food Engineering, 80(1), 111-118. doi:10.1016/j.jfoodeng.2006.04. 056

Izli, N. \& Isik, E. (2015). Color and microstructure properties of tomatoes dried by microwave, convective, and microwaveconvective methods. International Journal of Food Properties, 18(2), 241-249. doi:10. 1080/10942912.2013.829492

Izli, N., Yildiz, G., Unal, H., Isik, E., \& Uylaser, V. (2014). Effect of different drying methods on drying characteristics, colour, total phenolic content and antioxidant capacity of goldenberry (Physalis peruviana 1.) International Journal of Food Science and Technology, 49(1), 9-17. doi:10.1111/ijfs. 12266

Karaaslan, S. N. \& Tuncer, I. K. (2008). Development of a drying model for combined microwave-fan-assisted convection drying of spinach. Biosystems Engineering, 100(1), 44-52. doi:10 . $1016 / \mathrm{j}$. biosystemseng.2007.12.012

Karathanos, V. T. (1999). Determination of water content of dried fruits by drying kinetics. Journal of Food Engineering, 39(4), 337-344. doi:10 . 1016 / S0260 - 8774(98) 00132-0

Kassem, A. S. (1998). Comparative studies on thin layer drying models for wheat. In 13th international congress on agricultural engineering (Vol. 6, pp. 2-6).

Kudra, T. \& Mujumdar, A. S. (2002). General discussion: conventional and novel drying concepts. Advanced Drying Technologies, $1-26$.

Lebovka, N. I., Praporscic, I., Ghnimi, S., \& Vorobiev, E. (2005). Does electroporation occur during the ohmic heating of food? Journal of Food Science, 70(5), E308E311.

Madamba, P. S., Driscoll, R. H., \& Buckle, K. A. (1996). The thin-layer drying characteris- tics of garlic slices. Journal of Food Engineering, 29(1), 75-97. doi:10.1016/02608774(95)00062-3

Maskan, M. (2000). Microwave/air and microwave finish drying of banana. Journal of Food Engineering, 44(2), 71-78. doi:10. 1016/S0260-8774(99)00167-3

Meisami-asl, E., Rafiee, S., Keyhani, A., \& Tabatabaeefar, A. (2009). Mathematical modeling of kinetics of thin-layer drying of apple (var. golab). Agricultural Engineering International: CIGR Journal, Manuscript 1185, XI. September. Retrieved from http://www.cigrjournal.org/ index . php / Ejounral / article / view / 1185 / 1228

Midilli, A., Kucuk, H., \& Yapar, Z. (2002). A new model for single-layer drying. Drying Technology, 20(7), 1503-1513. doi:10.1081/ DRT-120005864

Minaei, S., Motevali, A., Najafi, G., \& Mousavi Seyedi, S. R. (2012). Influence of drying methods on activation energy, effective moisture diffusion and drying rate of pomegranate arils ('Punica granatum'). Australian Journal of Crop Science, 6(4), 584-591. Retrieved from http:// search . informit.com.au/documentSummary; $\mathrm{dn}=$ 361897809981770;res=IELHSS

Ozbek, B. \& Dadali, G. (2007). Thin-layer drying characteristics and modelling of mint leaves undergoing microwave treatment. Journal of Food Engineering, 83(4), 541549. doi:10.1016/j.jfoodeng.2007.04.004

Ozkan, I. A., Akbudak, B., \& Akbudak, N. (2007). Microwave drying characteristics of spinach. Journal of Food Engineering, $78(2)$, 577-583. doi:10.1016/j.jfoodeng. 2005.10 .026

Sacilik, K. (2007). The thin-layer modelling of tomato drying process. Agriculturae Conspectus Scientificus (ACS), 72(4), 343-349. Retrieved from http://hrcak.srce.hr/19403

Sarsavadia, P. N., Sawhney, R. L., Pangavhane, D. R., \& Singh, S. P. (1999). Drying behaviour of brined onion slices. Journal of Food Engineering, 40(3), 219-226. doi:10. 1016/S0260-8774(99)00058-8

Sharafeldeen, Y. I., Blaisdell, J. L., \& Hamdy, M. Y. (1980). A model for ear corn dry- 
ing. Transactions of the Asae, 23(5), 12611271.

Singh, A., Nair, G. R., Rahimi, J., Gariepy, Y., \& Raghavan, V. (2013). Effect of static high electric field pre-treatment on microwaveassisted drying of potato slices. Drying Technology, 31(16), 1960-1968. doi:10 . 1080/07373937.2013.805142

Soysal, Y. (2004). Microwave drying characteristics of parsley. Biosystems Engineering, 89(2), 167-173. doi:10 . 1016/ j . biosystemseng.2004.07.008

Sumnu, G. (2001). A review on microwave baking of foods. International Journal of Food Science and Technology, 36(2), 117-127. doi:10.1046/j.1365-2621.2001.00479.x

Contributor contact details. (2005). In H. Schubert \& M. Regier (Eds.), The microwave processing of foods (xi-xiii). Woodhead Publishing Series in Food Science, Technology and Nutrition. Woodhead Publishing. doi:10.1016/B978-1-85573-964-2.50018-7

Taheri-Garavand, A., Rafiee, S., \& Keyhani, A. (2011). Mathematical modeling of thin layer drying kinetics of tomato influence of air dryer conditions. International Transaction Journal of Engineering, Management \& Applied Sciences \& Technologies, 2(2), 147-160. Retrieved from http: / / www . i - scholar . in / index . php / ITJEMASTTUE/article/view/59079

USDA. (2014). United states department of agriculture. Accessed 02 February 2014. Retrieved from http://fnic.nal.usda.gov/

Vega-Galvez, A., Puente-Diaz, L., LemusMondaca, R., Miranda, M., \& Torres, M. J. (2014). Mathematical modeling of thinlayer drying kinetics of cape gooseberry (Physalis peruviana 1.) Journal of food processing and preservation, 38(2), 728-736. doi:10.1111/jfpp. 12024

Verma, L. R., Bucklin, R. A., Endan, J. B., \& Wratten, F. T. (1985). Effects of drying air parameters on rice drying models. Transactions of the Asae, 28(1), 296-301.

Wang, C. Y. \& Singh, R. P. (1978). A single layer drying equation for rough rice. ASAE paper No. 3001, ASAE, St Joseph, MI.

Wang, Z., Sun, J., Chen, F., Liao, X., \& Hu, X. (2007). Mathematical modelling on thin layer microwave drying of apple pomace with and without hot air pre-drying. Journal of Food Engineering, 80(2), 536-544. doi:10.1016/j.jfoodeng.2006.06.019

Xiao, H.-W., Pang, C.-L., Wang, L.-H., Bai, J.-W., Yang, W.-X., \& Gao, Z.-J. (2010). Drying kinetics and quality of monukka seedless grapes dried in an air-impingement jet dryer. Biosystems Engineering, 105(2), 233-240. doi:10 . 1016/j . biosystemseng . 2009.11.001

Yaldiz, O. \& Ertekin, C. (2001). Thin layer solar drying of some vegetables. Drying Technology, 19(3-4), 583-597. doi:10.1081/DRT100103936

Zarein, M., Samadi, S. H., \& Ghobadian, B. (2015). Investigation of microwave dryer effect on energy efficiency during drying of apple slices. Journal of the Saudi Society of Agricultural Sciences, 14(1), 41-47. doi:10. $1016 /$ j.jssas.2013.06.002

Zhu, A. \& Shen, X. (2014). The model and mass transfer characteristics of convection drying of peach slices. International Journal of Heat and Mass Transfer, 72, 345-351. doi:10.1016/j.ijheatmasstransfer.2014.01. 001 